\title{
小腸転移をきたした喉頭癌例
}

\author{
岸本曜・庄司和彦 ・池上聰 \\ 鈴木 慎二・丸毛みゆき*・児嶋剛
}

\section{A Case of Laryngeal Carcinoma Metastasizing to the Small Intestine}

\author{
Yo Kishimoto, Kazuhiko Shoji, Satoshi Ikegami, \\ Shinji Suzuki and Tsuyoshi Kojima \\ (Tenri Hospital) \\ Miyuki Marumo \\ (Hyogo Prefectural Amagasaki Hospital)
}

\begin{abstract}
We report a case of laryngeal carcinoma metastasizing to the small intestine. A 51-year-old man who had been treated for laryngeal carcinoma presented with abdominal pain. CT of the abdomen revealed hypertrophy of the ileum wall. There was an incomplete obstruction of ileum. After resection of the obstruction, the patient was free from abdominal pain and became able to eat. The specimen demonstrated an infiltration of the small intestine by squamous cell carcinoma, speculated to be from the larynx.
\end{abstract}

Key words : laryngeal carcinoma, metastasis, small intestine

はじめに

転移性小腸腫瘍の原発巣としてこれまで子宮頸癌, 悪 性黒色腫などが報告されているが，頭頸部癌からの遠隔 転移は非常にまれである.今回われわれは喉頭癌からの 小腸転移例を経験したので若干の文献的考察を加え報告 する.

\section{症例}

症例 : 51 歳, 男性.

主訴: 腹痛, 発熱.

既往歷：アルコール性肝硬変.

現病歷: 平成 14 年 2 月, $\mathrm{S}$ 状結腸㮩室炎穿孔に対し当 院腹部外科で手術を行った. 術前に行った上部消化管内 視鏡で喉頭に腫揚を指摘されたため 2 月 8 日当科紹介と なり, 精查の結果, 喉頭癌（声門上 T2N2bM0）と診断
された．肝硬変のため手術のリスクが高いことを説明し たところ，患者は放射線治療を希望し， 2 月 25 日から 4 月 8 日の間に $69.6 \mathrm{~Gy}$ の照射 (CDDP $50 \mathrm{mg} / \mathrm{body} /$ 週の化 学療法を併用) を行った。 照射終了時頸部リンパ節はほ とんぞ触知しなくなっていたため外来にて経過観察して いたが, 同年 7 月に頸部超音波検查にて右側頸部に腫大 したリンパ節を認め, 右保存的頸部郭清術を行った. 組 織検查にて扁平上皮癌のリンパ管浸潤を指摘された. 同 年 11 月にも右側頸部郭清範囲外に腫瘤を指摘され, 同部 の郭清を行った。この腫瘤にはリンパ節の構造はなく脈 管への転移が疑われた。

その後外来で経過観察していたが, 平成 15 年 4 月に右 耳下部に癌の再発を認めた。癌は頸動脈を囲むように存 在し境界不明瞭であった. 手術の適応はないと判断し対 症療法を行っていたところ, 5 月に発熱, 腹痛を主訴に 


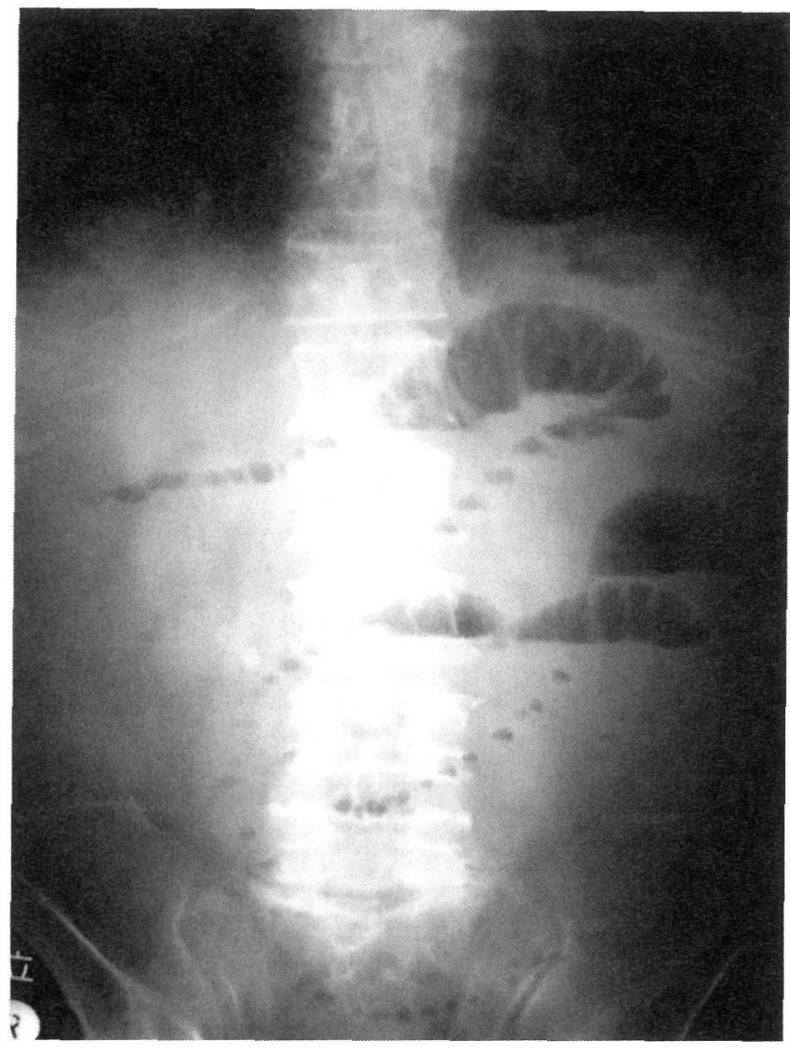

図 1 腹部 $\mathrm{X}$ 線

イレウスの像を呈していた。

当院救急外来を受診し，イレウスの診断で腹部外科入院 となった。

入院時理学的所見：貧血，黄疸を認め，栄養状態注不 良であった。喉頭の原発巣には再発を認めなかった。頸 部触診では右耳下部の腫張と同部の膿瘍形成を認め, 発 熱，炎症所見の原因と考えられた。腹部触診では右肋弓 下で肝を 3 横指触知し，臍部を中心に厓痛を認めた。

入院時一般検查所見 : 赤血球 : $304 \times 10^{4} / \mu 1, \mathrm{Hb}: 10.2$ $\mathrm{g} / \mathrm{dl}$, Ht : 29. 2\%, 白血球 : $12000 / \mu 1, \mathrm{CRP}: 8.3 \mathrm{mg} / \mathrm{dl}$, Plt: $15.4 \times 10^{4} / \mu \mathrm{l}, \mathrm{BUN}: 10.7 \mathrm{mg} / \mathrm{dl}, \mathrm{CRE}: 0.8 \mathrm{mg} / \mathrm{dl}$, TP: $7.2 \mathrm{~g} / \mathrm{dl}$, ALB $: 2.7 \mathrm{~g} / \mathrm{dl}$, LDH $: 159 \mathrm{IU} / \mathrm{L}$, GOT $: 26$ IU/L, T-Bil : $2.2 \mathrm{mg} / \mathrm{dl}$.

画像所見：腹部 X 線では niveau, Kerckring ヒダを認 めイレウスの像を呈していた（図1）.

胸部 CT では縱隔リンパ節は前縦隔リンパ節，気管傍 リンパ節，傍大動脈リンパ節，大動脈弓下リンパ節，気 管気管支リンパ節，気管分岐下リンパ節の腫大を認め， 癌性リンパ管症の像を呈していた。 その他両肺野に胸水,

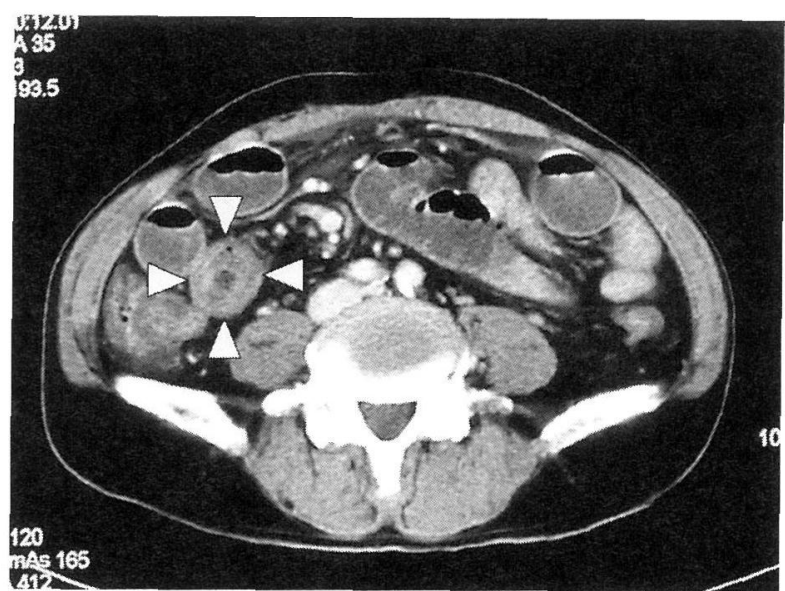

図 2 腹部 CT

壁肥厭に伴う不完全狭窄を認めた（ゆ).

左 S6 亿転移を認劝た。

腹部 CT では肝硬変像, 少量の腹水之, 下腹部に数カ 所の小腸狭窄を起点とした小腸の拡張を認めた。狭窄部 は管腔が保たれており不完全閉塞と考光られた（図 2).

小腸造影ではガストログラフィンの通過障害を認めた (図 3).

病歴より, 狭窄の原因として結腸想室炎術後の癒着, 喉頭癌の小腸転移, 感染・肝硬変に伴う末梢循環障害等 が疑われた。画像所見上，狭窄部が前回術創から離れて 多発していること，壁肥厚を伴うこと，狭窄部での屈曲 がないこと等より癒着によるものとは考えにくく，また 周囲の血管は造影されており，血流む保たれていること から循環障害によるものとも考えにくかった。 そのため, 喉頭癌の転移に伴亏小腸狭窄を第一に疑った。

イレウス管を挿入し一度は症状が軽減するも，経口摂 取を再開すると再びイレウスをきたすため保存的治療は 難しいと判断し，当院腹部外科と相談の上，手術を行っ た.

手術: 平成 15 年 6 月 30 日, 全身麻酔下に回腸部分切 除を行った (図 4). 前回手術による癒着は軽度であった。 回盲部より約 $100 \mathrm{~cm}$ の回腸に, 腸間膜付着部よりびまん 性に浸潤する腫瘍による約 $6 \mathrm{~cm}$ の全周性狭窄を認め, 同 部の腸間膜リンパ節は弾性硬に腫大していた。狭窄部に $3 \sim 4 \mathrm{~cm}$ のマージンを設け切除し, 根部のリンパ節も摘 出した。手術時間は 101 分, 出血量は $40 \mathrm{~g}$ であった.

摘出標本: 腫瘍の浸潤に伴う約 $6 \mathrm{~cm}$ の全周性狭窄を認 めた（図 5). 


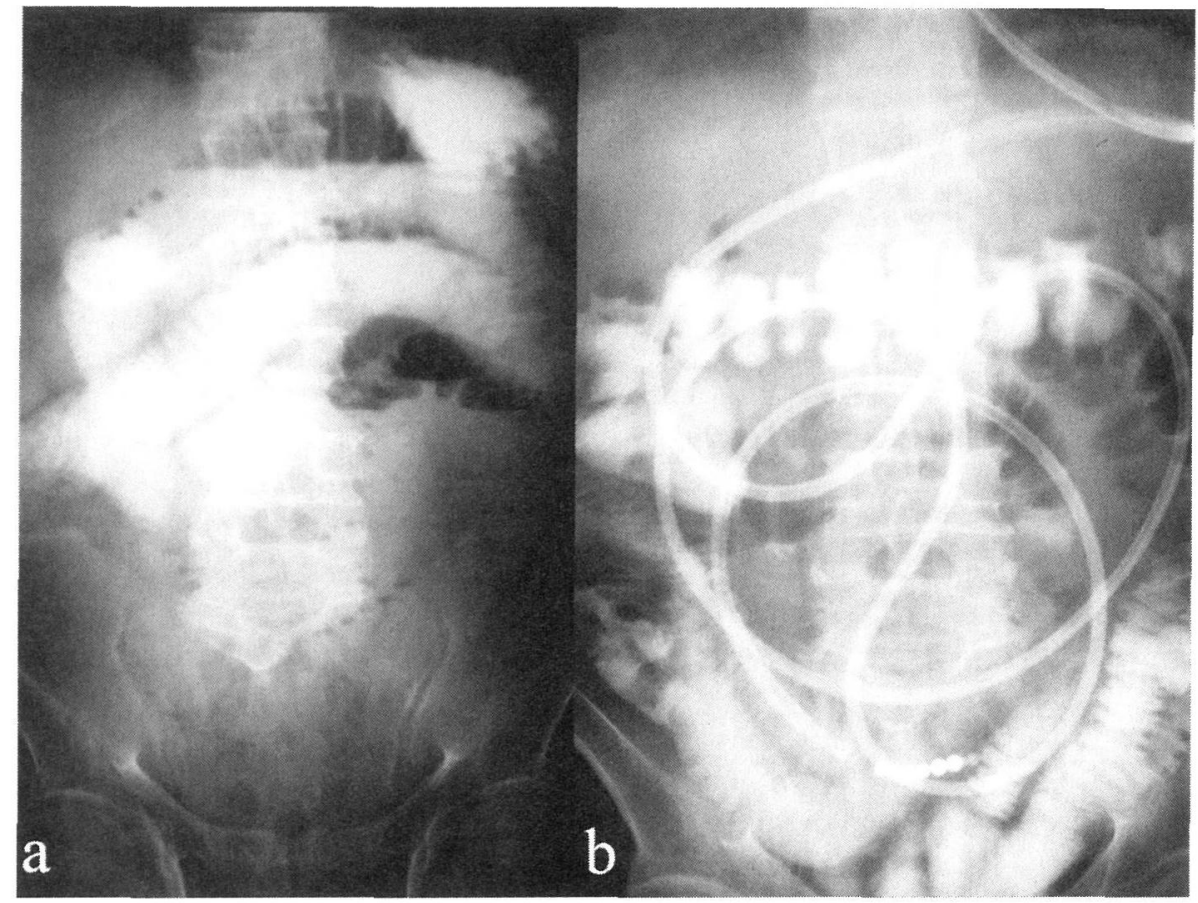

図 3 小腸造影

a：小腸での通過障害を認めた。

b ：イレウスチューブ挿入により大腸へのガストログラフィンの流出を認めた.

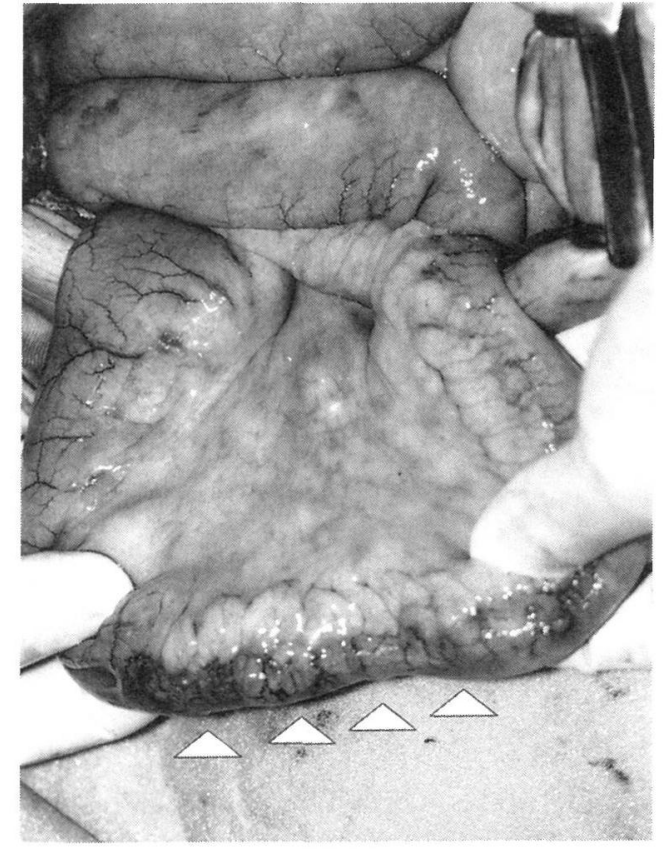

図 4 手術所見

回腸部分切除術を行った ( $\triangle$ : 狭窄部分).
病理所見：中分化型扁平上皮癌の浸潤性増殖が粘膜固 有層から漿膜下まで認められ，脈管侵襲も著明であった (図 6). 病歴，小腸での原発性扁平上皮癌の頻度の少な さより喉頭癌の転移と診断された。

術後経過：術後 4 日目より経口摂取が可能となり，退 院の上外来にて経過観察を行っていたところ, 平成 15 年 8 月に痤攣をきたした。頭部 CT を撮影したところ脳転 移が判明したため, 再度入院となった。保存的治療を続 けるも, その後全身状態は次第に悪化し同年 8 月 25 日死 亡された。剖検は家族の同意を得られず行わなかった。

\section{考按}

頭頸部癌の消化管への転移はまれである。小腸に関し ても同様であり，転移性小腸腫瘍の原発巣としては子宮 頸癌, 腎癌から, その他腹腔外臓器では悪性黒色腫, 肺 癌からであることが多いと報告されている12). 頭頸部領 域の原発巣としてはこれまで喉頭のほか, 上顎, 軟口蓋 等が報告されているがいずれも非常にまれである314).

喉頭癌の遠隔転移に関して諸家の報告を省みると, そ の頻度は $4.4 \sim 6.7 \%$ と報告されている5) 8). しかし, 


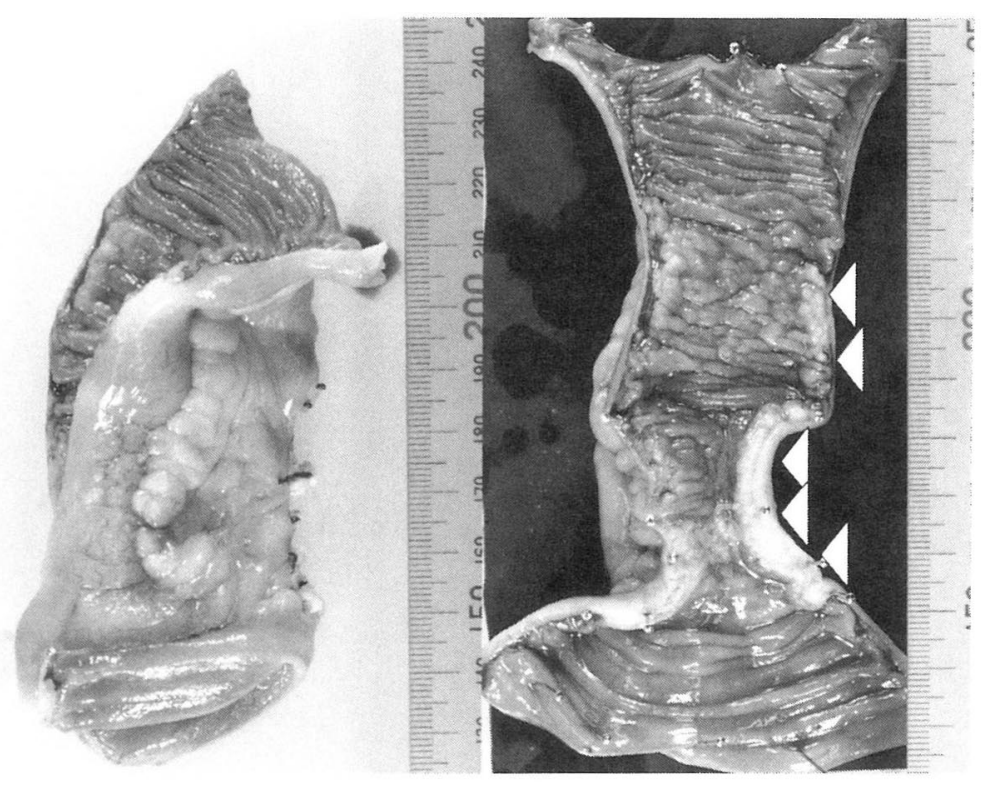

図 5 摘出標本

約 $6 \mathrm{~cm}$ の全周性狭窄を認めた (

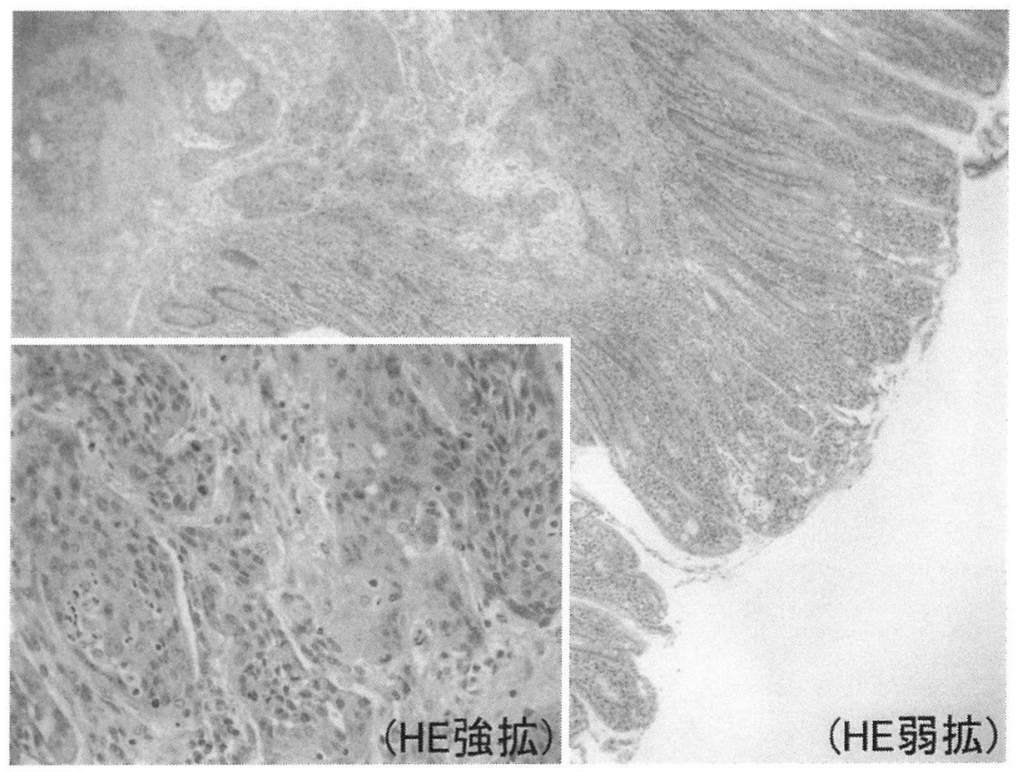

図 6 病理所見 中分化型扁平上皮癌々診断された.

剖検例を検討した報告では $50 \%$ にのぼるとの報告もあ り，実際の頻度はもら少し高いと考光られる ${ }^{9)}$ 。転移部 位としては肺, 骨, 肝が多いとされており, まれな部位 としては今回われわれが経験した小腸のほか, 膵, 胃等

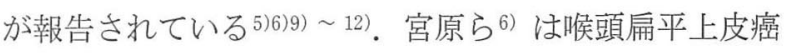

患者 213 例を検討し，遠隔転移の高危険群を transglottis を含む声閒上癌 T3，T4，N1， N2b， pN2c 例としている. また Yoshihara ら ${ }^{13)}$ は過去の報告を省み, 喉頭癌のうち 小腸転移をきたす危険性が高いものは声門上癌であると し, さらに転移部位に関しては, 空腸, 回腸のいずれも 
同程度の頻度としている. 今回の症例はやはり声門上癌 $\mathrm{N} 2 \mathrm{~b}$ 症例であり, 遠隔転移の高リスク群に属していたと 考えられる.転移性小腸腫瘍では患者は一般に腹部膨満, 腹痛, 便秘, 吐気・嘔吐等を訴え, 消化管の閉塞, 場合 によっては穿孔をきたす2)1415)。今回の症例では, 症状 出現の直前よりモルヒネの投与を開始していたため，モ ルヒネの副作用による便秘の増悪が疑われた。 そのため 画像検査を行うまでは症状と喉頭癌の遠隔転移の可能性 を結びつけることは難しかった。

頭頸部癌であっても悪性腫瘍患者が上記症状を訴える 場合, 消化管への転移の可能性を考慮に入れ, 腹部 X 線, CT, 小腸透視, 内視鏡等を行い, 狭窄, 腫瘍の有無を確 認するべきだと考えられる。その際重複癌の可能性も念 頭に置く必要がある.

小腸への転移形式としてはリンパ行性, バトソンの椎 骨静脈叢等を経る血行性，そして腹部手術等による腹膜 播種等が考えられる2)314). なかでも腹腔内臓器原発の場 合, 直接浸潤や，播種性転移によることが多く，通常， 管外性圧迫による狭窄をきたす4). Yamada ら ${ }^{14)}$ は転移性 腫瘍の腸管での顕在化を, 免疫防御機構の崩壊に伴う腫 瘍進展と結論づけているが，このように悪性腫瘍終末期 の一部分症としてとらえられることが多い.これに対し, 腹腔外臓器原発の場合, リンパ行性, 血行性に粘膜下層 や筋層に転移し, 出血, 潰瘍をきたしやすいとされてい る4). 今回の症例の場合は, 腸間膜リンパ節への転移を 認めたこと, 癌性リンパ管症をきたしていたこと等より リンパ行性転移の可能性，異時性ではあるが脳転移を認 めたこと, 肺転移を認めたこと等より血行性転移の可能 性のいずれも考え得る16) 18).

治療に関しては，閉塞をきたしている場合，激しい痛 みを伴うため, 全身状態が許すなら手術による閉塞部位 の切除を選ぶべきだと考える．われわれが涉編し得た限 りにおいては，化学療法により改善を示したという報告 はなかった，小腸転移をきたす症例は，前述のとおり， 通常はいわゆる悪性腫瘍終末期であることが多く, 基本 的に予後は不良である. そのため, 予後の改善というよ りむしろ患者の QOL の改善を目的とすべきであり，予 後を考慮した必要最小限の手術は患者にとって非常に有 益であると考える．本症例においても手術により患者は 腹痛などの腹部症状から解放され, 経口攝取が可能と なった。諸家の報告でも転移性小腸腫瘍に対して姑息的 な治療として切除を考慮す心゙きであると考察されてい
$ろ^{2) 19) 20)}$.

$$
\text { まとめ }
$$

非常にまれな喉頭癌小腸転移症例を経験した. 進行癌, 特に声門上癌においては腹部症状を訴えた場合，腹腔臓 器への遠隔転移の可能性を念頭に置く必要があると考え られた。 さらに小腸の閉塞をきたしている場合は，QOL の改善のため同部位を切除することを考慮に入れる必要 があると考えられた。

\section{参考文献}

1) Poteshan NL : Metastatic tumor to the small bowel; three cases simulating primary malignant tumors. Am J Roentgenol Radium Ther Nucl Med $99: 122 \sim$ 126, 1967.

2) de Castro CA, Dockerty MB and Mayo CW : Metastatic tumors of the small intestines. Surg Gynecol Obstet $105: 159$ $\sim 165,1957$.

3) Routh A and Hickman BT : Metastatic tumors of the small intestine; case report and review of literature. J Miss State Med Assoc 25 : $235 \sim 236,1984$.

4）若原正幸, 田中千凱, 種村廣巳, 他 : 回腸に転移した上顎 癌の 1 例. 日臨外 $61: 628 \sim 631,2000$.

5）近藤 隆, 河辺義孝：喉頭癌遠隔転移例の検討. 耳鼻臨床 $77: 1459 \sim 1466,1984$.

6）宮原 裕, 家根旦有, 鶴田至宏, 他：喉頭癌の臨床的検討. 日耳鼻 $105: 790 \sim 798,2002$.

7) Spector JG, Sessions DG, Haughey BH, et al. : Delayed regional metastases, distant metastases, and second primary malignancies in squamous cell carcinomas of the larynx and hypopharynx. Laryngoscope $111: 1079 \sim 1087,2001$.

8) Spector GJ : Distant metastases from laryngeal and hypopharyngeal cancer. ORL J Otorhinolaryngol Relat Spec 63:224 $228,2001$.

9) Lam KY and Yuen AP : Cancer of the larynx in Hong Kong; a clinico-pathological study. Eur J Surg Oncol $22: 166 \sim 170$, 1996.

10）系数哲郎, 古謝静男, 真栄城徳秀, 他: 当科における進行 喉頭癌 (stage III, IV) 症例の検討. 耳喉頭頸 $71: 27 \sim 30$, 1999.

11）伊藤 敬, 先本秀人, 中原英樹, 他：膵転移をきたした喉 頭癌の 1 例. 広島医学 $42: 969 \sim 972,1989$.

12）若林 透, 川嶋 彰, 武田 正, 他: 喉頭癌由来と考えら れた転移性胃扁平上皮癌の 1 例. Endoscopic Forum for Digestive Disease 5:81 84, 1989 .

13) Yoshihara $T$ and Yamamura $Y$ : An unusual case of laryngeal carcinoma metastasizing to the small intestine. J Laryngol Otol 
$111: 575 \sim 577,1997$.

14) Yamada $T$, Yagi $S$, Tatsuzawa $Y$, et al. : Small intestinal metastasis from esophageal carcinoma associated with small intestinal obstruction; report of a case. Surg Today $26: 800 \sim$ 802, 1996.

15) Ise $\mathrm{N}$, Kotanagi $\mathrm{H}$, Morii $\mathrm{M}$, et al. : Small bowel perforation caused by metastasis from an extra-abdominal malignancy; report of three cases. Surg Today 31:358 362, 2001.

16) Alavi S, Namazie A, Sercarz JA, et al. : Distant lymphatic metastasis from head and neck cancer. Ann Otol Rhinol Laryngol $108: 860 \sim 863,1999$.

17) Buyukcelik A, Ensari A, Sarioglu M, et al. : Squamous cell carcinoma of the larynx metastasized to the ampulla of Vater; report of a case. Tumori $89: 199 \sim 201,2003$.
18) Yucel EA, Demirel T, Demiryont $M$, et al. : An unusual metastatic site of laryngeal carcinoma; scapular muscles. J Laryngol Otol $117: 85 \sim 87,2003$.

19) Wang M, Patel J, Casey TT, et al. : Metastatic squamous cell carcinoma from the esophagus occurring as small bowel obstruction. South Med J $78: 884 \sim 886,1985$.

20) Airoldi M, Gabriele P, Succo G, et al. : Small bowel metastasis from squamous cell carcinoma of the larynx; a case report. Tumori $79: 286 \sim 287,1993$.

原稿受付：平成15年12月11日

原稿採択：平成16年 1 月 14 日

別刷請求先 : 岸本 曜

T632-8552 天理市三島町200

天理よろづ相談所病院耳鼻咽喉科 